\title{
Evaluation of insecticides against stemborers in maize
}

\author{
M. Anuradha
}

Agricultural Polytechnic, Palem, Nagarkurnool (Telangana) India

\section{ARITCLE INFO}

Received : 30.12 .2019

Revised : 13.03 .2020

Accepted : 26.03.2020

\section{KEY WORDS :}

Stem borer, Insecticides, Infestation, Deadhearts

*Corresponding author:

Email : kasuanu@yahoo.co.in

\begin{abstract}
In the field experiments conducted during Kharif 2012 and Rabi 2012-13 at Maize Research Centre, Rajendranagar to find out an alternative to endosulfan which was recommended against stem borer in maize, insecticides were sprayed at the recommended dosages at 12 DAG and observations were recorded at $45 \mathrm{DAG}$ and subjected to RBD analysis after angular transformation. Mean infestation was observed to be the lowest in the plot treated with chlorantriniliprole $18.5 \mathrm{SC}(1.28 \%)$ followed by £cyhalothrin 5CS $(2.33 \%)$. Mean per cent deadhearts was lowest i.e., 0.41 in the $f$-cyhalothrin treated plot followed by 0.61 in Indoxacarb treatment.
\end{abstract}

How to view point the article : Anuradha, M. (2020). Evaluation of insecticides against stemborers in maize. Internat. J. Plant Protec., 13(1) : 98-100, DOI : 10.15740/HAS/IJPP/13.1/98-100, Copyright@ 2020: Hind Agri-Horticultural Society. 